\title{
Evaluating the $4^{\text {th }}$ November 2015 Flash Flood Disaster: A Case Study in Wadi An-Natrun and Wadi Al-Farigh Depressions, The Western Desert, Egypt
}

\author{
Amr Mohamed Sabry Mahsop Saleem*
}

\begin{abstract}
Flash floods are among natural hazards frequently recorded in Egyptian deserts. By the November 4, 2015 a sever flash flood hit the northwestern part of the Nile Delta and the surrounding desert margin in Wadi An-Natrun and Wadi Al-Farigh Depressions. This event left large economic damage and fatalities. In the current study, field work has been carried out in disaster sites, namely in Wadi An-Natrun and Wadi Al-Farigh. This allows a detailed observation of flood impacts. Also Landsat-based spectral indices and GIS change detection operations are utilized in quantifying damage. It is found that physical factors such as exceptional rainfall event and topography control flood runoff and inundation. Moreover, miss-land use in the study area yields a disastrous flash flood. [Bul. Soc. Géog. d'Égypte, 2017, 90: 1-20]
\end{abstract}

Key Words: Flash floods; Desert; Inundation; Damage; Landsat; Spectral indices

\section{Introduction}

In deserts, flash floods occasionally occur within dry valleys "wadis" and floodout terrains. These events are characterized by the relatively short duration of ephemeral water flow, rarely more than one day (Lin, 1999). Flash floods are typically a product of exceptional rainfall events. They are often of high intensity and highly localized in space and time (Wiggs, 2011). For example, in Saudi Arabia, more than $90 \mathrm{~mm}$ of rainfall during four hours caused runoff and widespread damage in the Jeddah area (Al-Bassam et al., 2014). Furthermore, bare soils, sparse vegetation and steep slope surfaces give high potentiality for desert surface runoff and flooding (Foody et al., 2004; Wainwright and Bracken, 2011). Usually, flash flood disasters are related to unmanaged human occupation of desert environments.

* Department of Geography, Faculty of Arts, Ain Shams University, Cairo, Egypt. For Correspondence: e-mail: amr_saleem@art.asu.edu.eg 
Catastrophic floods in Egypt go back to the nineteenth century. On the November 14, 1895 fifteen buildings collapsed and widespread inundation was recorded east of Cairo City, following heavy rainfall (Khidr, 1997). Most of flash floods are recorded in mountainous areas, such as the Sinai Peninsula, the Red Sea coast and the Eastern Desert (Gabr and El Bastawesy, 2015; Moawad et al., 2016; Abdalla et al., 2014). Less is known about rare floods in the Western Desert.

On 17 and 18 January 2010, Egypt witnessed major flash floods. These events were well documented in some localities on Sinai and Upper Egypt, accompanied by casualties and widespread damage. In Northern Sinai, the damage was prominent in the main trunk of Wadi El-Arish. Flood water swept away properties, pipelines and public constructions. Moawad (2012) reports that six people killed and there was a loss of some properties worth about 137 million Egyptian pounds. The January 2010 floods hit South Sinai, along the Gulf of Suez in Wadi Sudr and Wadi Wardan. Surface runoff led to widespread destruction of human settlements, highways, and infrastructure (Abdel-Lattif and Sherief, 2012). On November 2, 1994 a worser flash flood occurred in Drunka village, Upper Egypt. Rushed water after being freed from the railway embankment destroyed four oil tanks which were constructed in the floor of Wadi Drunka. After a few hours, water inundation, fires and heavy smoke invaded the Village of Drunka. There was severe destruction of buildings, cultivated land, livestock and cemeteries. 399 people were killed (Ashour, 2002).

Among previous studies some deal with areas-objects vulnerability to flood hazards (El-Khrachy, 2015; El-Sherpiny et al., 2015), while some others concentrate on post-disaster assessments. Regarding the former, field work, GIS and remote sensing are essential tools of research. The November 25, 2009 severe flooding of Jeddah inspires some of flood assessment studies. For example, Al-Saud (2010) used high-resolution IKONOS satellite images that allowed the identification of flooded areas. Topographic maps and DEM are used to delineate and analyze inundated watersheds. Youssef et al., (2015) present field observations of damage in Jeddah's urban area, in the watershed of Wadi Qus.

On the early morning of the November 4, 2015 torrential rain fell in the regions of Alexandria and El-Beheira, northwest of the Nile Delta. Widespread inundation was reported in many locations, e.g. some tunnels in the Cornish of Alexandria, International Airport of Burg El-Arab and ElRahmaniah administration, El-Beheira Governorate. It left significant economic losses and large number of victims in Wadi An-Natrun and WadiAl-Farigh Depressions. 
The current study focuses on the $4^{\text {th }}$ November 2015 flood disaster in An-Natrun and Al-Farigh Depressions. The main objectives of the study are: 1) to quantify flooding-inundation damage based on Landsat data and field observations, 2) to understand the causative factors (physical and maninduced) and 3) to present recommendations to help management desert flash flood hazards in the future.

\section{Geographic Settings}

Wadi An-Natrun and Wadi-Al-Farigh Depressions are located in the Western Desert of Egypt, some 40 kilometers west of the Nile Delta. Wadi An-Natrun depression has a unique elongated shape, along SE-NW axis for $60 \mathrm{~km}$, with an average width of $5.4 \mathrm{~km}$. Two opposite escarpments determine this depression, the upper limit of the eastern escarpment corresponds to elevations 30 to 40 meters above sea level, however the western escarpment rises up to $170 \mathrm{~m}$ a.s.l, near to Jabal Hadid (Figure 1). The whole area of An-Natrun depression is around $1090 \mathrm{~km}^{2}$, of which $23 \%$ lies below sea level. The northwest sector of the depression lies at $19 \mathrm{~m}$ b.s.l.

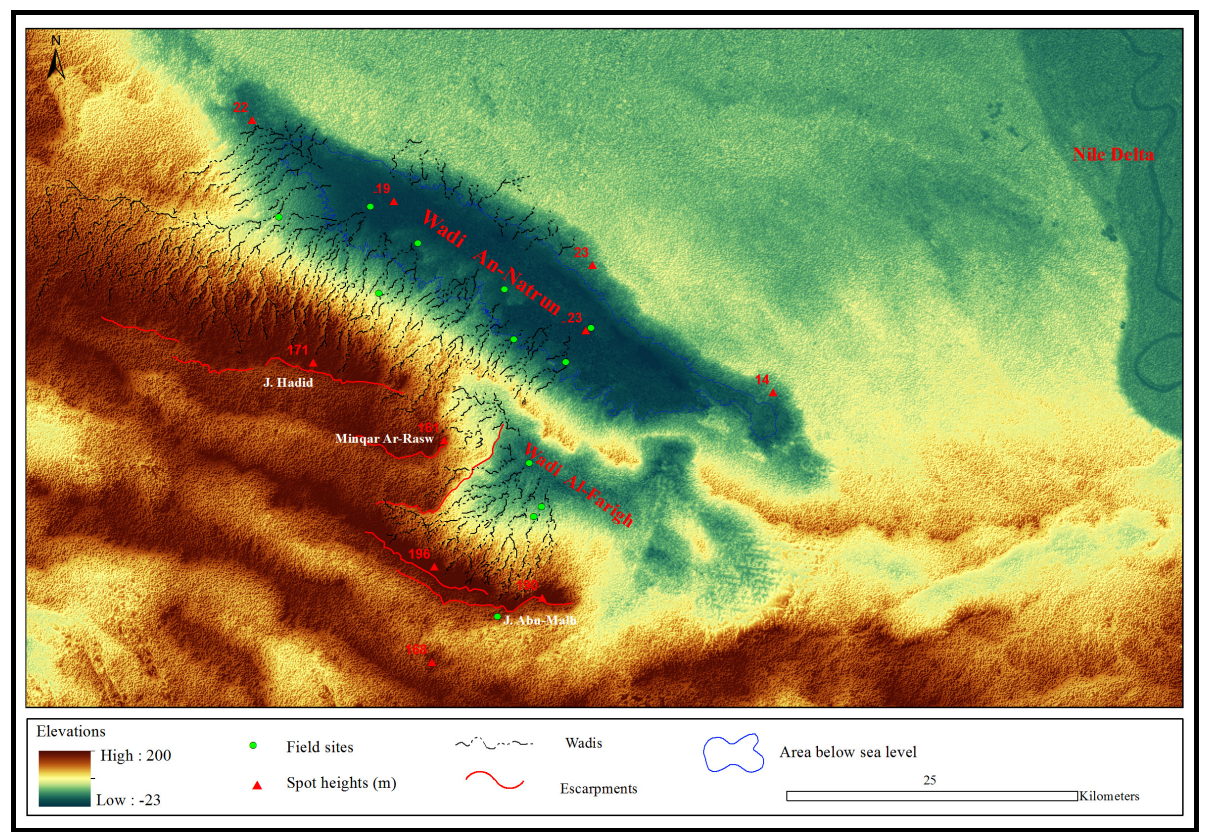

Figure 1. Digital Elevation Model of the study area.

Some ephemeral lakes occupy the topographic lows. They have a linear pattern of distribution as well as SE-NW axis of An-Natrun (Figure 2). The number, area and depth of the lakes vary seasonally according to water 
supply and evaporation. All the lakes are fed by a water aquifer (Embabi, 2004). Dry wadis have incised the two escarpments of An-Natrun Depression. Most of them concentrate across northwest escarpment. All drainage basins have internal discharge flow patterns to the floor of the depression. Wadi Raqabt El-Haytah is the largest drainage basin (Figure 2). It consists of two sub-basins covering $302 \mathrm{~km}^{2}$, the northern sub-basin has a fifth-order trunk wadi (Table 1).

Table 1. Morphometric characteristics of some drainage basins in the study area.

\begin{tabular}{|l|c|c|c|c|c|}
\hline \multicolumn{1}{|c|}{ Drainage basin } & $\begin{array}{c}\text { Area } \\
\left(\mathbf{k m}^{2}\right)\end{array}$ & $\begin{array}{c}\text { Ordered- } \\
\text { trunk stream }\end{array}$ & $\begin{array}{c}\text { Length } \\
(\mathbf{k m})\end{array}$ & $\begin{array}{c}\text { Elevation } \\
\text { range (m) }\end{array}$ & Slope \\
\hline $\begin{array}{l}\text { Raqabt El-Haytah, } \\
\text { North (WN) }\end{array}$ & 205 & 5 & 28.8 & 169 & $1 / 5.8$ \\
\hline $\begin{array}{l}\text { Raqabt El-Haytah, } \\
\text { South (WN) }\end{array}$ & 97 & 4 & 17.4 & 186 & $1 / 10.6$ \\
\hline Dayr Al-Adhra (WN) & 7 & 3 & 5.1 & 102 & $1 / 20$ \\
\hline Minqar A-Rasw (WF) & 39 & 4 & 7.9 & 131 & $1 / 16.5$ \\
\hline Iwyan (WF) & 18 & 3 & 9.4 & 140 & $1 / 14.8$ \\
\hline Abu Milha (WF) & 78 & 5 & 13.5 & 170 & $1 / 12.5$ \\
\hline Saber (WF) & 25 & 4 & 10.8 & 166 & $1 / 15.3$ \\
\hline
\end{tabular}

WN: Wadi An-Natrun, WF: Wadi Al-Farigh

Wadi Al-Farigh is a neighboring depression parallel to An-Natrun, of the same SE-NW orientation. It extends for $22 \mathrm{~km}$ long. The maximum width of the floor depression (below the $10 \mathrm{~m}$ a.s.l contour) is $4.8 \mathrm{~km}$ in the northwest section. The elevation range of the depression is about $200 \mathrm{~m}$. Three escarpments delimit the depression from the east, north and west (Figure 1). The western and northern escarpments are overlooked by three hills (Jabal Abu-Malh +190 m a.s.l, Jabal Qanitarah + 196 m a.s.l and Minqar Ar-Rasw + $161 \mathrm{~m}$ a.s.l). They are a headwater of wadi networks descending to the floor of the depression.

The climate of the study area is characterized by arid conditions with some Mediterranean influence. Analysis of the meteorological norms between 1975-2005 indicates that the average annual temperature in AnNatrun is $21^{\circ} \mathrm{C}$. In the summer and winter seasons, the average daily temperatures are $27.3^{\circ} \mathrm{C}$ and $14.1^{\circ} \mathrm{C}$ respectively. Rainfall in the study area is associated with centers of low pressure. The former dominate northern Egypt between November and February. 


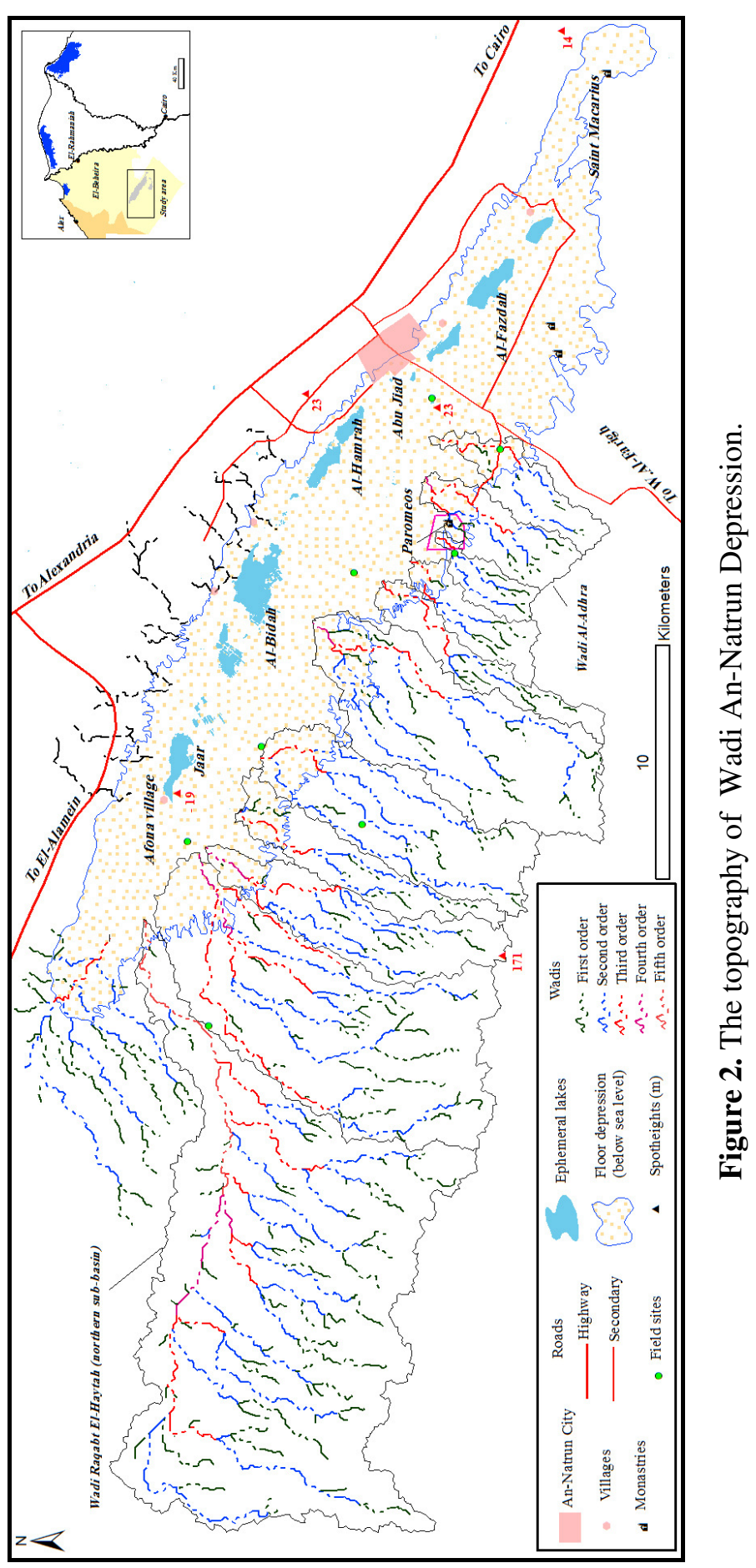

$-5-$ 
The concentration of large amounts of rainfall during short time periods constitutes a high flood risk. The metrological archive of sixty years (19452005) in Wadi An-Natrun shows that the maximum amount of rainfall in one day was $79 \mathrm{~mm}$ on the November 17, 1980. During the same period, only eleven days witnessed torrential rainfall of more than $10 \mathrm{~mm}$ per day. Moreover the summer months are totally dry (Table 2).

Table 2. The maximum rainfall in one day, Wadi An-Natrun ground station, 1945-2005.

\begin{tabular}{|l|c|c|}
\hline \multicolumn{1}{|c|}{ Month } & $\begin{array}{c}\text { Max. rainfall amount } \\
\text { in one Day (mm) }\end{array}$ & Date \\
\hline January & 18.0 & $30 / 1 / 1956$ \\
\hline February & 24.0 & $28 / 2 / 1953$ \\
\hline March & 14.9 & $22 / 3 / 1991$ \\
\hline April & 27.0 & $10 / 4 / 1956$ \\
\hline May & 8.0 & $8 / 5 / 1946$ \\
\hline June & 0.0 & -- \\
\hline July & 0.1 & $18 / 7 / 1982$ \\
\hline August & 0.0 & -- \\
\hline September & 2.5 & $28 / 9 / 2000$ \\
\hline October & 6.0 & $7 / 10 / 1994$ \\
\hline November & 79.0 & $17 / 11 / 1980$ \\
\hline December & 33.0 & $6 / 12 / 1955$ \\
\hline
\end{tabular}

Source: Egyptian Meteorological Authority.

Wadi Al-Farigh "in Arabic Empty" mostly was uninhabited until 2000 AD. Wadi An-Natrun is among nine mega-depressions of the Egyptian Sahara that have supported human living. Early human occupation in Wadi An-Natrun is attested back to Roman time (Shortland et al., 2011). Wadi AnNatrun hosts four historical monasteries, the oldest being Saint Macarius which was founded in the fourth century AD. Nowadays, An-Natrun administration center belongs to El-Beheira governorate, with an estimated (190,000 inhabitants in 2016), that comprises An-Natrun City and five villages with satellites.

\section{Methods}

\section{1) Satellite Images Processing}

\section{a. Landsat Dataset and Pre-processing}

The Landsat datasets are widely used in detecting episodic changes caused by floods in various environments (Memon et al., 2015; Mukherjee and Samuel, 2016; NASA EARTH Observatory). Landsat images are accessible using the USGS's Earth Explorer web browser (online) available 
at:" "http://earthexplorer.usgs.gov/". The current study mainly utilizes two Landsat 8 OLI scenes for accurate measurements of flood damage. These images were captured on September 17, 2015 and December 6, 2015 (Table $3)$. The Landsat $8 \mathrm{~L} 1 \mathrm{~T}$ products are geometrically corrected based on the UTM projection. To enhance Landsat 8 image, several pre-processing tasks are implemented such as:

- Atmospheric correction which is an essential pre-processing task to remove atmospheric scattering and absorption noise and it is important when using ratio transformations. Digital numbers are converted to the top of atmospheric spectral reflectance (TOA) applying standard equations (USGS) such as:

$$
\rho \lambda^{\prime}=M_{\rho} Q_{c a l}+A_{\rho}
$$

Where $\rho \lambda$ ' is the TOA planetary reflectance, without correction for solar angle, $\mathrm{M}_{\rho}$ is band-specific multiplicative rescaling factor in Landsat 8 metadata file, $\mathrm{A}_{\rho}$ is band-specific additive rescaling factor in Landsat 8 metadata file and $\mathrm{Q}_{\mathrm{cal}}$ is Quantized and calibrated standard product pixel values $(D N)$.

$$
\rho \lambda=\rho \lambda^{\prime} / \sin \left(\theta_{S E}\right)
$$

Where $\rho \lambda$ is the TOA planetary reflectance, with correction for solar angle and $\theta_{\mathrm{SE}}$ is the sun elevation angle in the metadata file.

- $\quad$ Band composite and sub-scene clipping: The combination of single spectral bands to multiple bands raster file allows colored visualization of Landsat data. Topographic features are recognized in display false color composite image. For examples, Near infra-red, Red and Green color highlights vegetation in bright red. Land/water is well discernible using short wave NIR, Red and Blue. The Landsat 8 standard scene covers $185 \times 185 \mathrm{~km}$. The whole study area of interest is covered by scene (path177, row 39). Seven sub scenes are clipped for further image processing.

Table 3. The Landsat dataset utilized for the current study.

\begin{tabular}{|c|c|c|c|c|l|}
\hline Satellite & Sensor & $\begin{array}{c}\text { Path } \\
\text { /Row }\end{array}$ & $\begin{array}{c}\text { Acquisition- } \\
\text { Date }\end{array}$ & $\begin{array}{c}\text { * Cloud- } \\
\text { Cover \% }\end{array}$ & $\begin{array}{c}\text { Image } \\
\text { specification (use) }\end{array}$ \\
\hline Landsat 8 & OLI & $177 / 39$ & $17 / 9 / 2015$ & 0.33 & Pre-flood image \\
\hline Landsat 8 & OLI & $177 / 39$ & $6 / 12 / 2015$ & 1.64 & Post-flood image \\
\hline Landsat 7 & ETM+ & $177 / 39$ & $12 / 8 / 1999$ & 0.00 & $\begin{array}{l}\text { Reference image of } \\
\text { land cover long- } \\
\text { term change and } \\
\text { checking drainage } \\
\text { networks }\end{array}$ \\
\hline
\end{tabular}

$*$ Cloud cover overlapping study area $=0.00$ 


\section{b. Spectral Indices}

The spectral index comprises the process of extraction target-based pixels (e.g. water or vegetation) from a satellite image applying algebraic calculations of multispectral bands. Application of this method depends on the thresholding approach (Liu et al., 2016). The threshold selection yields a binary classified thematic layer (e.g. water and non-water).

Several spectral indices are applied for extraction and monitoring of water bodies, for example NDWI (Rokni et al., 2014), MNDWI (Hereher, 2015), and AWI (Feyisa et al., 2014). Furthermore, Wu (2014) lists seventeen of spectral vegetation indices that widely applied in terrestrial ecosystem research. The current study applies two spectral indices as follows:

- Modified Normalized Difference Water Index (MNDWI): McFeeters

(1996) has submitted Normalized Difference Water Index as:

$$
N D W I=(\rho \text { green }-\rho \text { NIR }) /(\rho \text { green }+\rho N I R),
$$

Where $\rho$ green and $\rho$ NIR are equivalent to OLI spectral bands 3 (green) and 5 (Near-IR) respectively.

This water index maximizes the reflectance of the waterbody by using green wavelength, minimizing the low reflectance in NIR of water bodies and take advantages of the high reflectance in Near-IR of vegetation. Usually, water bodies are given a positive threshold value $>0$.

$\mathrm{Xu}$ (2006) has developed Modified Normalized Difference Water Index after McFeeters's NDWI as:

$$
M N D W I=(\rho \text { green }-\rho M I R) /(\rho \text { green }+\rho M I R)
$$

Where $\rho$ green and $\rho$ MIR are equivalent to OLI spectral bands 3 (green) and 6 (SWIR) respectively.

Xu's MNDWI gives the advantage of removal noise background built up area that is confused with targeted water bodies.

- $\quad$ Normalized Difference Vegetation Index (NDVI): is a pioneer index that has been presented by Tucker (1979) as:

$$
N D V I=(\rho \mathrm{NIR}-\rho \text { red }) /(\rho \mathrm{NIR}+\rho \text { red })
$$

Where $\rho$ NIR and $\rho$ reed are equivalent to OLI spectral bands 5 (Near-IR) and 4 (red) respectively.

The NDVI acts conversely to the NDWI, in this index vegetation is prominent as it has a high reflectivity in the Near-IR. 
The above mentioned MNDWI and NDVI are applied to TOA reflectance. These include both pre-flood and post-flood images. The threshold values of the waterbody and vegetation are identified based on a visual interpretation of Landsat images as well as using field reference data.

\section{2) Field work}

Three field trips were carried out from December 2015 to February 2016. These trips mainly aim to observe a near real time damage. The field work allows quantifying flood impacts on sample sites in detail. Cross sections are used to survey flood water erosion and associated damage. In the field, a direct communication was carried out with eyewitnesses and other stakeholders such as farm owners and governmental administrations.

In the current study, field work and remote sensing techniques were integrated. Observing post-flood Landsat image helps to discern inundated sites. Furthermore, field reference data were used in remote sensing processing.

\section{3) GIS analyses}

The SRTM Digital Elevation Model, topographic maps (Eleven sheets, scale 1/50000) and field data were manipulated in a GIS. All these datasets are co-registered in UTM projection. Basic GIS operations were carried out including: 1) digitizing of geospatial elements such as contours, wadi networks, roads and built up areas, and 2) overlay-extract operations of raster and vector layers. The most important GIS analyses are:

a. Hydrological analyses: ArcGIS-hydrology modeling tools were used based on SRTM DEM. The Arc GIS-hydrology model comprises an essential tool to determine flow direction and calculating flow accumulations (Esri, 2011). Applying this model allows automated extraction of wadi networks and watersheds. The product wadis were overlain with a Landsat ETM+ image to check their accuracy. The wadi networks within each watershed are given orders according to Strahler (1957).

b. Change detection: Simple arithmetic operations of image radiance or derivative features can be used to highlight areas of change (Tewkesbury et al., 2015). In the current study, the addition operation of two spectral indices allows calculating changes of vegetation and waterbodies. The Arc GIS model builder is used to formulate spectral indices and consequently calculate some arithmetic operations (Figure 3). 


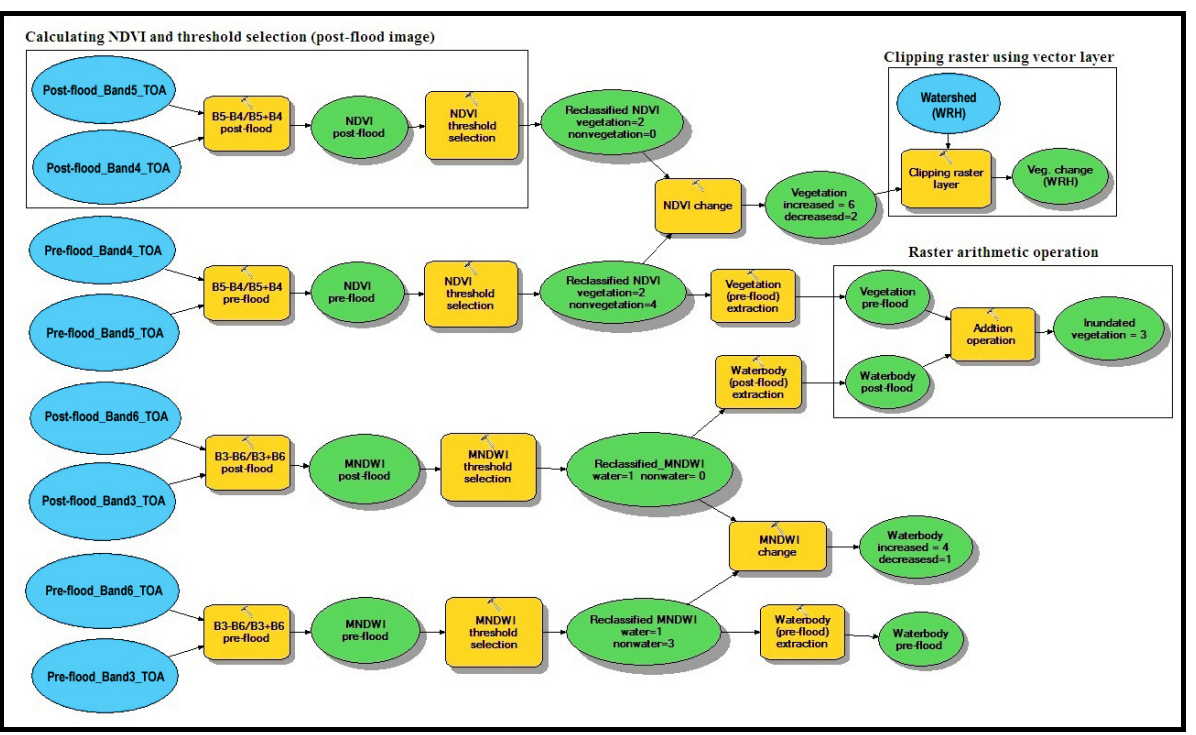

Figure 3. GIS operations using Arc GIS Model Builder.

\section{Results and Discussion}

The $4^{\text {th }}$ November 2015 flash flood led to widespread damage in Wadi AnNatrun and Wadi-Al-Farigh. Direct damage occurred by two processes: 1) surface runoff and 2) water inundation. Most of the inundation concentrated in the floor of both depressions. Significant increases in the areas of the existing lakes of Wadi An-Natrun are observed, in addition to the formation of new ephemeral ponds. In both depressions, the surface area of water bodies increased by $240 \%$, that includes the pre-flood existing lakes and new lakes. Detailed case studies of flood devastation were carried out at six sample sites.

\section{1) Wadi An-Natrun}

a. Paromeos area

This area occupies the central part of the floor of An-Natrun Depression. It extends along the side of the road connecting An-Natrun City and Paromeos monastery and it is crossed by some shallow wadis, such as Wadi Al-Adhra (Figure 2). The following damage was recorded along the Paromeos road:

- A new ephemeral pond was found a few meters from the main electricity control unit of An-Natrun City. This pond was 2 meters deep immediately after the flooding and fell to 1.2 meters two months later. The trapping of water caused the damage of 12 acres cultivated by vegetable crops and the breakdown of the electric power transformer (Figure 9-a). The former costs about 40000 EGP.

- About $0.2 \mathrm{~km}$ north of the pond, severe damage is observed. The obstruction of water flow against masonry structures generated return 
water currents which may have caused a vertical cut of asphalt up to 1.7 meters and the exposure of electric cables (Figure 9-b). Flowing water destroyed farm walls and uprooted some palm trees.

\section{b. Al-Bidah - Jaar (Lakes area)}

Al-Bidah - Jaar area located in the northwestern part of Wadi An-Natrun. The whole area lies below sea level and it comprises a floodout area of six drainage basins, including two sub-basins of Wadi Raqabt ElHaytah (Figure 2). Water from these areas yield severe flooding.

Landsat-based analysis indicates that surface area of the water body suddenly increased by $218 \%$. Al-Bidah and Jaar Lakes were joined to form just one waterbody. All of the fish farms found in between the two lakes were drowned. More minor levels of damage in cultivated land were recorded on the margins of the two lakes. However, spot inundation damage on a large farm was quantified as 107.6 acres (Figure 4). Field work allowed observing disaster close to Jaar Lake (Figure 9-c). The houses of the village of Afona were totally destroyed and the village is ruined. Most people were left homeless. According to one villager "some neighbors are still lost underwater".

\section{c. Wadi Raqabt El-Haytah (WRH)}

Agriculture is the most common form of land use in Wadi Raqabt ElHaytah. The lower section of (WRH) drainage basin is densely occupied by small farms. Orchards are common in middle and upper sections. Detailed field work was carried out in two orchards. Torrential surface runoff swept hundreds of punica trees, destroyed a barrier of Casurina trees and left irrigation pipelines broken (Figure 9-e). According to the farm owners, the average cost of orchard restoration is 30000 EGP per acre, which includes a cumulative cost of construction irrigation networks and the cultivation of trees in five years.

Figure (5) shows a clear decrease in the area of cultivated land after the flood event. Most of the damage is concentrated in the lower section of Wadi Raqabt El-Haytah, because a large quantity of water is collected in this area. The total damage of cultivation within the drainage basin was estimated to be 4300 acres.

\section{2) Wadi Al-Farigh}

\section{a. Depression Floor}

The flash flood created 22 new ephemeral ponds in Wadi Al-Farigh. The largest three ponds are found in the northwest depression close to Wadi AlFarigh entrance. This area is fed by flood water from three drainage basins (Wadi Minqar A-Rasw, Wadi Iwyan and Wadi Abu Milha). Water accumulation damaged 271 acres of cultivated land including one circled pivot farm. By contrast, most ponds overlie barren land in the central area. In this area, 19 new pivot farms appeared after the flood event (Figure 6). 

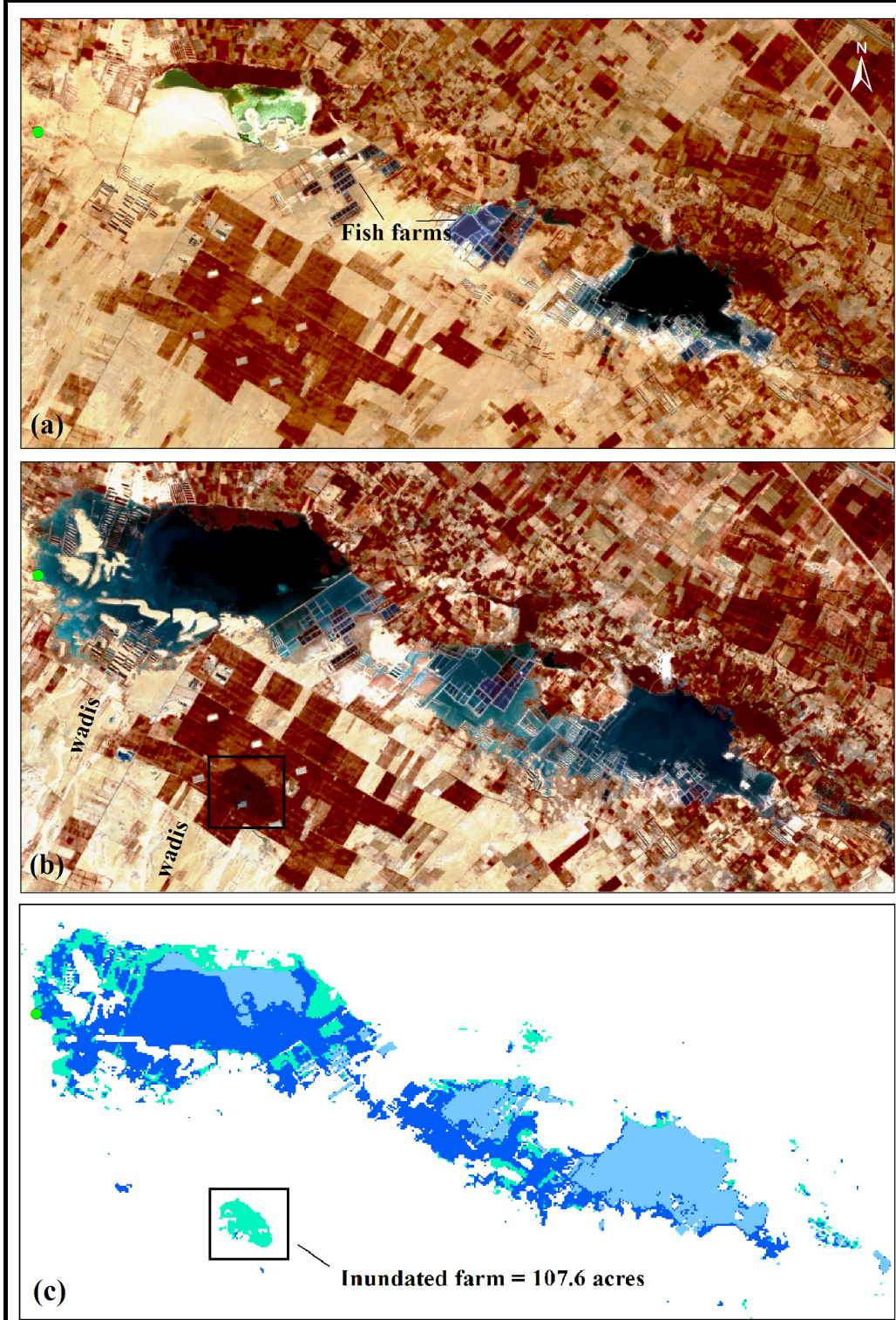

Pre-flood waterbody (no change)

Vegetation to waterbody

Barren land to waterbody

(a) Pre-flood image

(b) Post-flood image

(c) Change detection based on NDWI and NDVI indices

Figure 4. Water inundation (Al Bidah - Jaar Lakes).

$-12-$ 

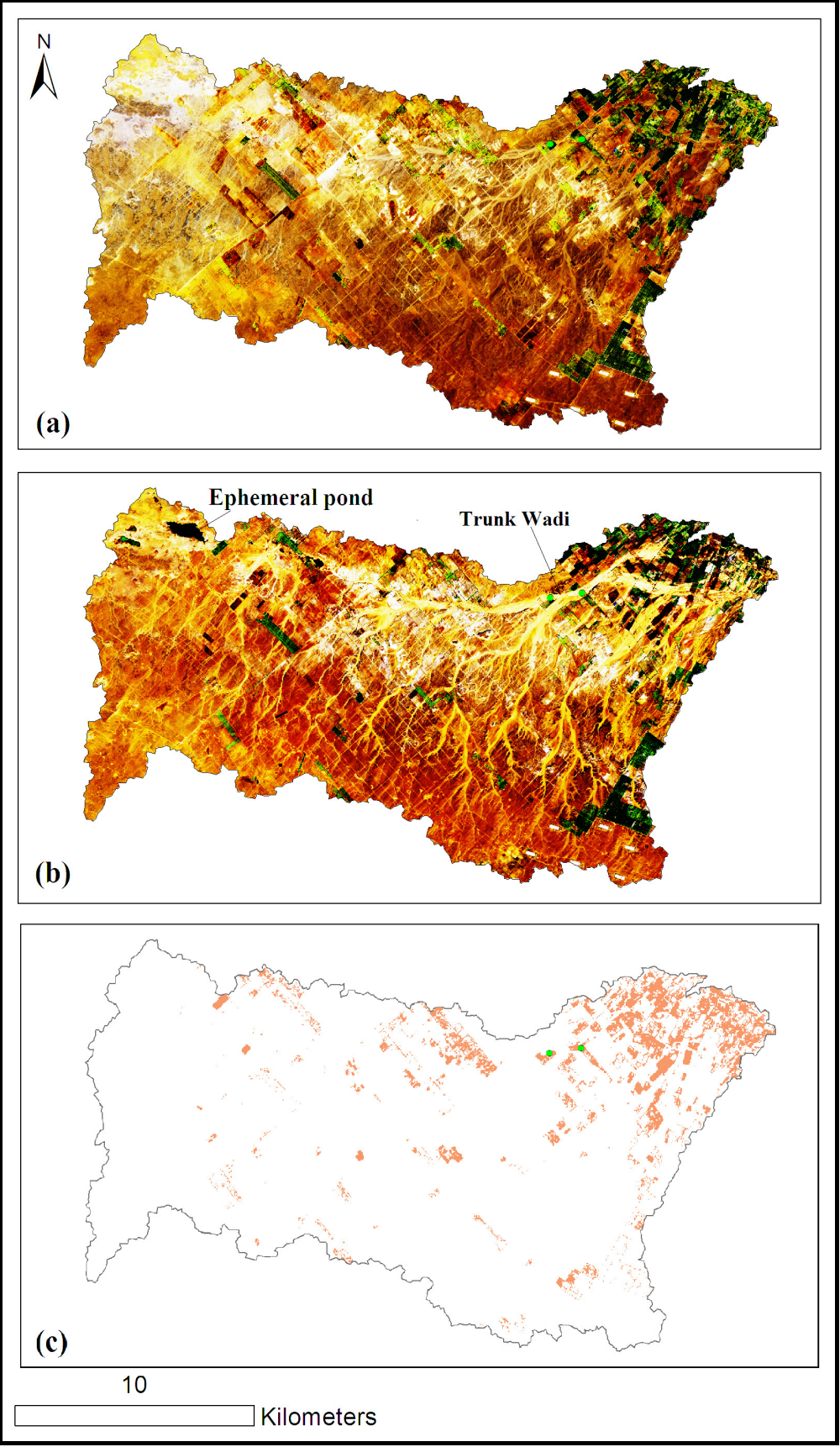

(a) Pre-flood image

(b) Post-flood image (note that flood sediments clearly appear inside wadi networks) (c) Damaged cultivation

Figure 5. Change detection in Wadi Raqabt El-Haytah. 


\section{b. Wadi Saber}

The drainage basin of Wadi Saber is located in the western escarpment of Wadi Al-Farigh. It covers $25 \mathrm{~km}^{2}$ (Figure 6). Agricultural land use is mainly composed of small fruit and vegetable farms. We traced flood damage in downstream (Site Grape garden $30^{\circ} 12^{\prime} 44.8^{\prime \prime} \mathrm{N} 30^{\circ} 17^{\prime} 02.1^{\prime \prime} \mathrm{E}$ ): This small farm covers 20 acres. Surface runoff damaged vines and green-bean crops. It severely damaged cultivation and irrigation facilities, about 2 acres of vine were totally destroyed (Figure 9-d). We observed that water gullied in soil up to 1.7 meters (Figure 7). According to the owner, the cost of restoration is 5000 EGP per acre, which includes refilling lost soil and the construction of a new irrigation system.

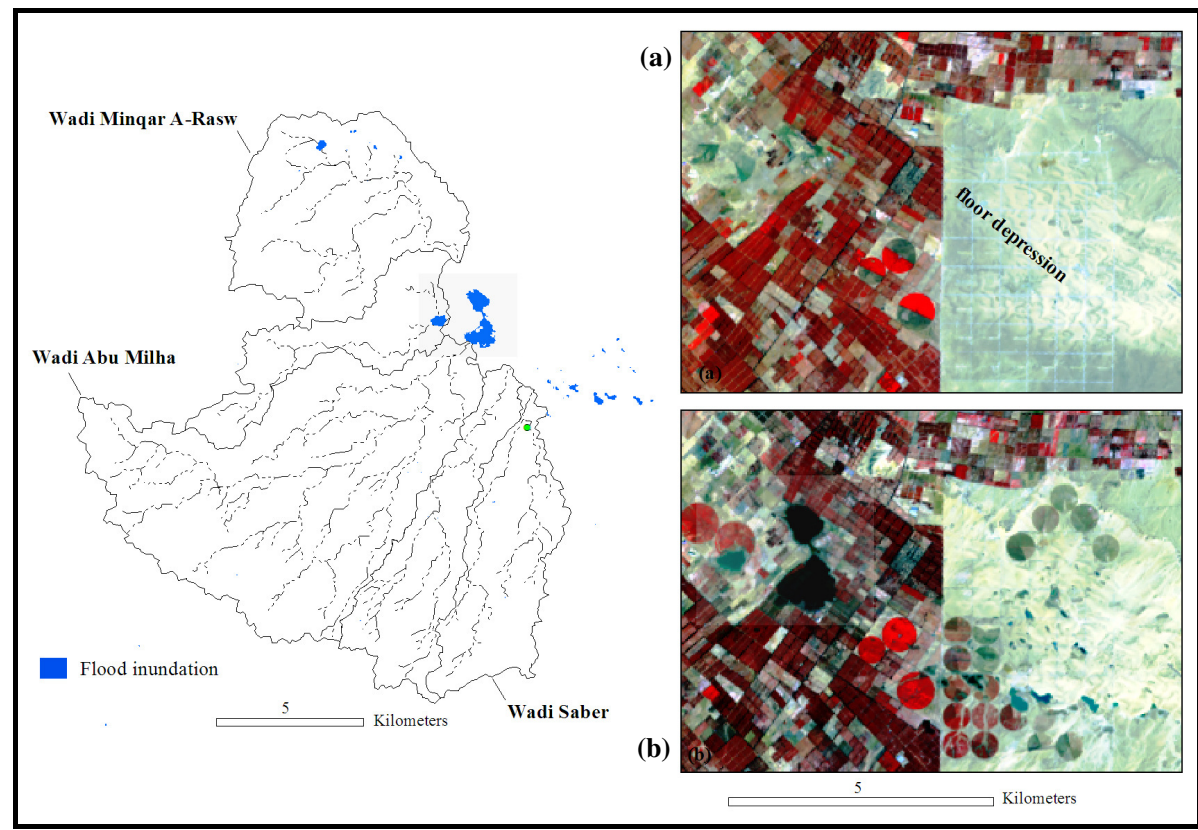

a: pre-flood image

b: post-flood image

Figure 6. Water inundation (floor depression, Wadi Al-Farigh).

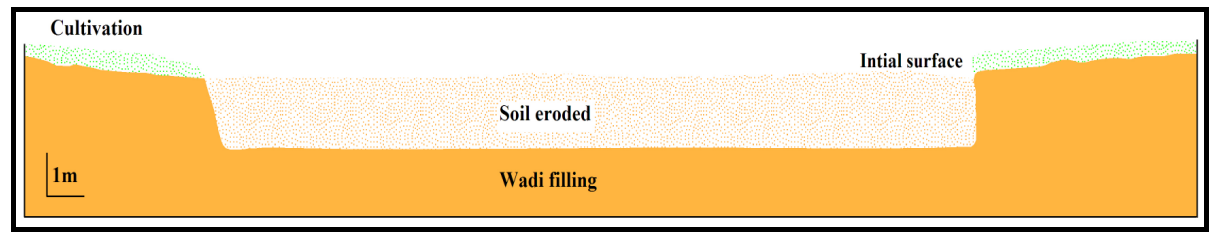

Figure 7. Cross profile shows soil erosion in Wadi Saber downstream.

$-14-$ 


\section{c. Daltex Farm}

Daltex mega farm covers approximate 7000 acres. It consists of 24 center pivots and three agricultural basins. This large farm is located inside a sub-depression attached to Wadi Al-Farigh, west of Jabal Abu-Malh (Figure 8).

\section{The flood affected Daltex farm as follows:}

- Water inundation impacts $2 \%$ and $9 \%$ of center pivots no. 41 and no. 20 respectively. Flooding also caused direct damage of 5.7 acres in large cultivated basin. Water was derived from short wadis which drain the Daltex depression.

- Center pivot no. 60 reconstructed on a steep slope side of Daltex depression. However, this pivot was not directly inundated although field investigation showed that a fresh gully broke pivot no. 60 and deepened it (Figure 9-f).

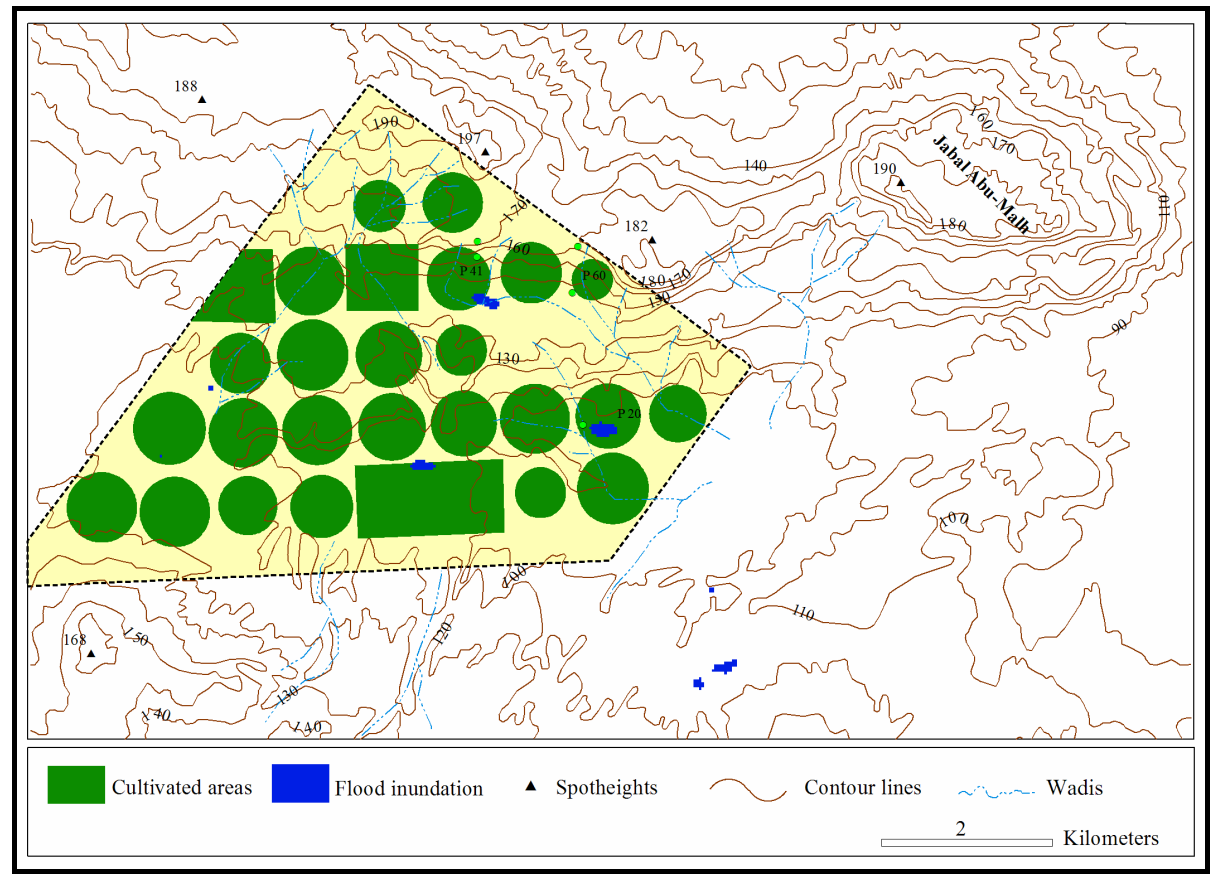

Figure 8. The Daltex mega farm (Wadi Al-Farigh).

The physical and anthropogenic factors responsible for the above mentioned damage can be presented as follows: 

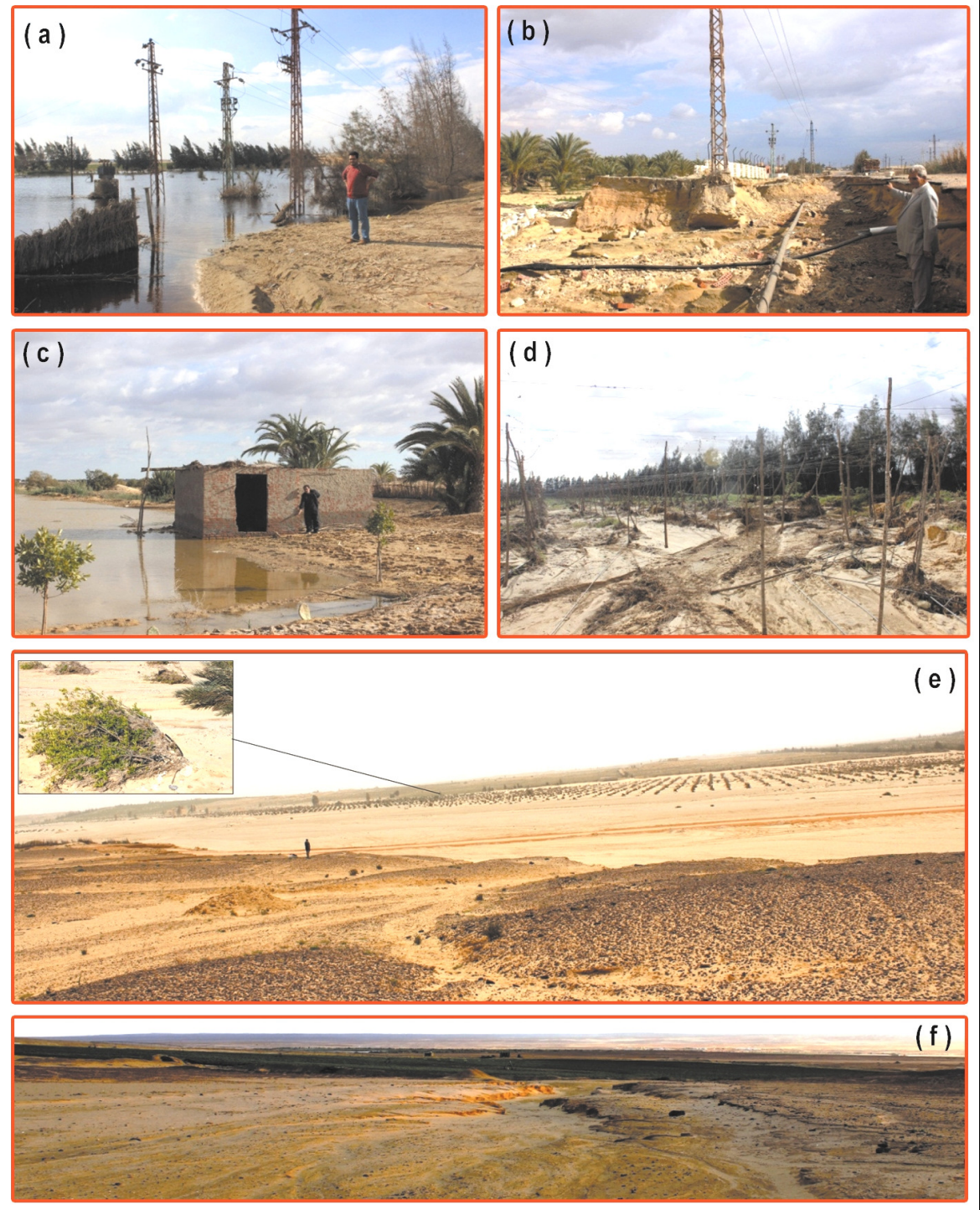

(a) Flood water accumulation (An-Natrun - Paromeos road)

(b) Flood water erosion and damaged asphalt (An-Natrun - Paromeos road)

(c) The expansion of Jaar lake (Afona village). Note the water marker on a building (photo taken January 1, 2016)

(d) Damaged vines trees and soil erosion (Wadi Saber)

(e) Damaged punica trees (trunk of Wadi Raqabt El-Haytah). The bent down tree (inset photo) indicates water flow direction

(f) Gully headwater eroded in center pivot no.60 (Daltex farm)

Figure 9. Field observations of flood impacts in Wadi An-Natrun and Wadi Al-Farigh

$-16-$ 
- The exceptional rainfall event triggered surface run off and flood inundation. JAXA GLOBAL RAINFALL WATCH offers hourly global rainfall maps in near real time, (online) available at: "http://sharaku.eorc.jaxa.jp/GSMaP/index.htm". The monitoring of rainfall during 3 and 4 November 2015 (Figure 10) shows that: 1) on 3 November, there was no rainfall in the study area before (17: 00 UTC), 2) slight rainfall $(0.1$ to $2 \mathrm{~mm} / \mathrm{h})$ was recorded during the next hour (17: 00 - 17: 59 UTC), thereafter rainfall was continuous for seventeen hours, and 3) by the early morning hour (3: $00-3$ : 59 UTC) on 4 November torrential rainfall $(25$ to $30 \mathrm{~mm} / \mathrm{h}$ ) struck the northwest margin of the Nile Delta, including the study area.

- The topographic characteristics mediated water-induced damage. The intensive hydraulic action of running surface water caused severe damage, especially inside trunk wadis. Water inundations were concentrated in topographic lows. For example, in Wadi An-Natrun 97\% of water inundation found below contour line - $10 \mathrm{~m}$.

- The human occupation of the study area is characterized by the miss-use of drainage basins and their floodout areas. For example, many of the trunk wadis are crossed by linear infrastructures, and they are blocked by buildings and trees. Most watersheds are totally imprinted by green cultivation. It is clear that human activities effectively alter the hydrological system which exacerbates the negative impacts of flash flood.

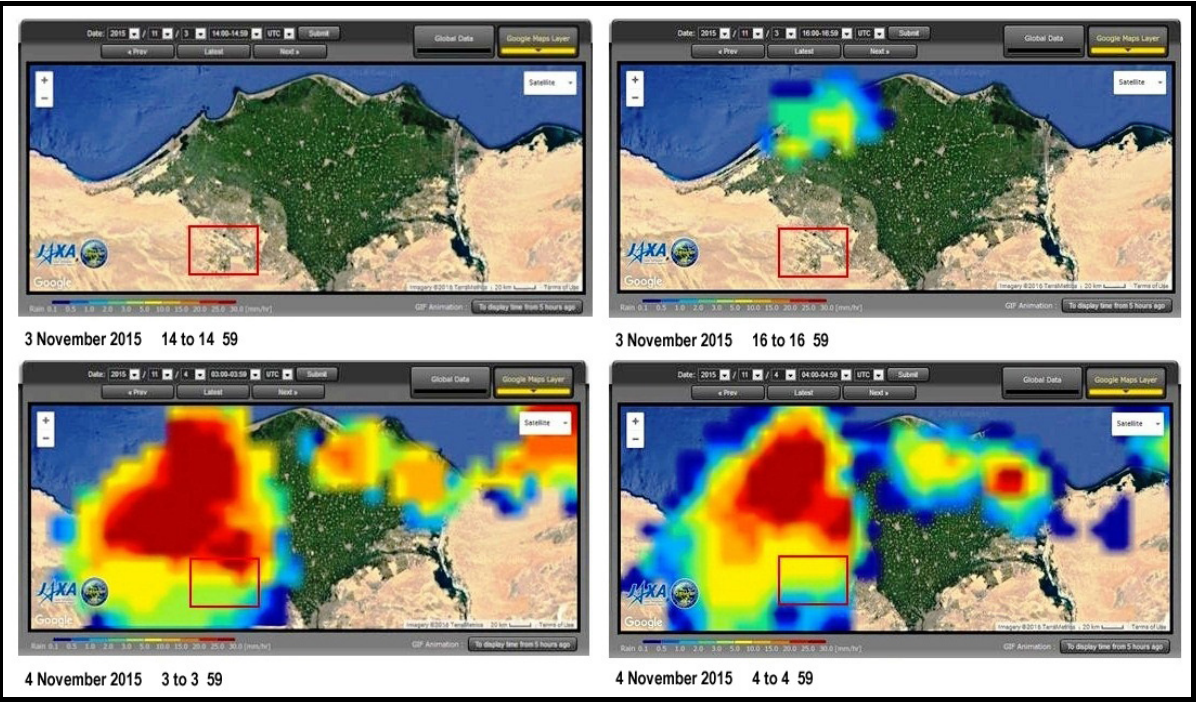

Figure 10. The progress of rainfall over the study area during the flash flood event ( 3 and 4 November 2015). 


\section{Conclusion and Recommendations}

The $4^{\text {th }}$ November 2015 flash flood hit the western margin of the Nile Delta. It destroyed infrastructure and public utilities (e.g. roads, pipelines and electricity), demolished many private buildings and incurred large number of injuries and deaths. In the current study, we have looked to evaluate losses caused by flash flood in Wadi An-Natrun and Wadi Al-Farigh. The combined remote sensing and field observations allowed us to estimate economic losses in some areas.

The last flood disaster underscores the need for a mitigation strategy for flash flood hazards in Egypt. This must include: 1) vulnerability assessment aiming at disaster prevention, and 2) post-disaster assistance for recovery and reconstruction (Hualou, 2011). This approach should be applied in the study area as follows:

- $\quad$ The currently occupied floodout areas in Wadi An-Natrun and Wadi AlFarigh should be free of large buildings and constructions. The agriculture land use should be controlled in the non-occupied areas of Wadi Al-Farigh and surrounding areas. For example prohibition of agriculture land use inside trunk wadis.

- Engineering measures are required to reduce the negative impacts of flash flood hazard. In Egypt, several measures have been adopted to mitigate the flash flood as a combination of obstacle dams and artiftial lakes downstream (Abdel-Fattah et al., 2015). These protective structures were not present in the study area before November 2015. Taking into consideration the topographic setting, wadis characteristics and land use, the current study suggests the construction of wadi embankments, culverts and underground water reservoirs.

- Remote Sensing and GIS tools effectively used at post flash flood period. Using these geo-informatics technologies in a real time of flood crisis helps in quick human aids and they allow accurate evaluation of flash flood disaster.

\section{Acknowledgment}

The author is grateful to professor Saber El-Desouki (Banha University, Egypt), for hospitality and sincere help during the field work. Thanks for Professor Nick Marriner (CNRS, Besançon, France), for useful comments and English corrections.

\section{References}

1. Abdalla, F., El Shamy, I., Bamousa, A.O., Mansour, A., Mohamed, A., Tahoon, M., 2014. Flash floods and groundwater recharge potentials in arid land alluvial basins, Southern Red Sea Coast, Egypt. Int. J. Geosci., 5: 971-982. 
2. Abdel-Fattah, M., Kantouch, S., Sumi, T., 2015. Integrated management of flash flood in wadi system of Egypt: disaster prevention and water harvesting. A. Disas. Prev, Res. Inst. Kyoto Univ., 58(B): 485-496.

3. Abdel-Lattif, A., Sherief, Y., 2012. Morphometric analysis and flash floods of Wadi Sudr and Wadi Wardan, Gulf of Suez, Egypt: using digital elevation model. Arab J. Geosci., 5: 181-195.

4. Al Saud, M., 2010. Assessment of Flood Hazard of Jeddah Area 2009, Saudi Arabia. J. Water Res. Prot., 2: 839-847.

5. Al-Bassam, A.M., Zaidi, F.K., Hussein, M.T., 2014. Natural hazards in Saudi Arabia. In Extreme Natural Events, Disaster Risks and Societal Implications, (Editors: A. Ismail-Zadeh, J. Urrutia-Fucugauchi, A. Kijko and I. Zaliapin). Cambridge University Press, pp. 243-251.

6. Ashour, M.M., 2002. Flash floods in Egypt (a case study of Drunka village Upper Egypt). Bul. Soc. Géog. d'Égypte, 75: 101-114.

7. El-Khrachy, I., 2015. Flash Flood hazard mapping using satellite images and GIS tools: a case study of Najran City, Kingdom of Saudi Arabia (KSA). Egypt. J.Remote Sens. Space Sci., 18: 261-278.

8. El-Sherpiny, M., El-Mewafy, M., Hegazy, I., 2015. The effect of flash flood on the efficiency of roads networks in South Sinai, Egypt. Case study (NuweibaDahab Road). Int. J. Sci. Eng. Res. (IJSER), 6(9): 544-548.

9. Embabi, N.S., 2004. The geomorphology of Egypt (landform and evolution). Vol. I, The Nile Valley and the Western Desert. A special publication of The Egyptian Geographical Society, Cairo.

10. Esri, Arc GIS Resource Center, 2011 Hydrologic analysis applications,. (Online) available at: http://help.arcgis.com/en/arcgisdesktop/10.0/help/index.html

11. Feyisa, G.L., Meilby, H., Fensholt, R., Proud, S.R., 2014. Automated water extraction index: a new technique for surface water mapping using Landsat imagery. Remote Sens. Environ., 140: 23-35.

12. Foody, G.M., Ghoneim, E.M., Arnell, N.W., 2004. Predicting locations sensitive to flash flooding in an arid environment. J. Hydrology, 292: 48-58.

13. Gabr, S., El Bastawesy, M., 2015. Estimating the flash flood quantitative parameters affecting the oil-fields infrastructures in Ras Sudr, Sinai, Egypt, during the January 2010 event. Egypt. J.Remote Sens. Space Sci., 18: 137-149.

14. Hereher, M.E., 2015. Assessing the dynamics of El-Rayan lakes, Egypt, using remote sensing techniques. Arab J. Geosci., 8: 1931-1938.

15. Hualou, L., 2011. Disaster prevention and management: a geographical perspective. Disaster Advances, 8(1): 3-8.

16. Khidr, M.M., 1997. The main geomorphological hazards in Egypt (in Arabic). Unpublished M.Sc. Thesis. Department of Geography, Faculty of Arts, Ain Shams University, Cairo, Egypt.

17. Lin, X., 1990. Flash floods in arid and semi-arid zones. International Hydrological Programme. UNESCO, pp. 1-60.

18. Liu, Z., Yao, Z., W, R., 2016. Assessing methods of identifying open water bodies using Landsat 8 OLI imagery. Environ. Earth Sci. 75: 873. DOI:10.1007/s12665-016-5686-2

19. McFeeters, S.K., 1996. The use of the normalized difference water index (NDWI) in the delineation of open water features. In. J. Remote Sens., 17: 1425-1432. 
20. Memon, A.A., Muhammad, S., Rahman, S., Haq, M., 2015. Flood monitoring and damage assessment using water indices: a case study of Pakistan flood2012. Egypt. J. Remote Sens. Space Sci., 18: 99-106.

21. Moawad, B.M., Abdel-Aziz, A.O., Mamtmin, B., 2016. Flash floods in the Sahara: a case study for the 28 January 2013 flood in Qena, Egypt. Geomatics Nat. Hazards and Risk, 7(1): 215-236.

22. Moawad, B.M., 2012. Analysis of the flash flood occurred on 18 January 2010 in Wadi El Arish, Egypt (a case study). Geomatics Nat. Hazards and Risk, 4(3): 254274.

23. Mukherjee, N.R., Samuel, C., 2016, Assessment of the temporal variations of surface water bodies in and around Chennai using Landsat imagery. DOI: 10.17485/ijst/2016/v9i18/92089

24. NASA Earth Observatory, Chapala Drenches the Desert. (Online) Available at: http://earthobservatory.nasa.gov/IOTD/view.php?id=86940

25. Rokni, K., Ahmad, A., Selamat, A., Hazini, S., 2014. Water feature extraction and change detection using multitemporal Landsat Imagery. Remote Sensing, 6: 41734189.

26. Shortland, A., Degryse, P., Walton, M., Geer, M., Lauwers, V., Salou, L., 2011. The evaporation deposits of Lake Fazda (Wadi Natrun, Egypt) and their use in Roman glass production. Archaeometry, 53(5): 916-929.

27. Strahler, A.N., 1957. Quantitative analysis of watershed geomorphology. Am. Geophys. Uni. Trans. 38, 913-920.

28. Tewkesbury, A.P., Comber, A.J., Tate, N.J., Lamb, L., Fisher, P.F., 2015. A critical synthesis of remotely sensed optical image change. Remote Sens. Environ., 160: 114.

29. Tucker, C., 1979, Red and photographic infrared linear combinations for monitoring vegetation. Remote Sens. Environ. 8(2): 127-150.

30. USGS (United States Geological Survey), Landsat Mission, Using the USGS Landsat 8 Product, 2015.

(Online) available at: http://landsat.usgs.gov/Landsat8_Using_Product.php

31. Wainwright, J., Bracken, J.B., 2011. Runoff generation, overland flow and erosion on hillslopes. In Arid zone geomorphology: process, form and change in drylands, third Edition, (Editor: D.S. Thomas). John Wiley \& Sons, pp. 237-267.

32. Wiggs, G.F.S., 2011. Geomorphological hazards in drylands. In Arid zone geomorphology: process, form and change in drylands, third Edition, (Editor: D.S. Thomas). John Wiley \& Sons, pp. 583-598.

33. Wu, W., 2014. The generalized difference vegetation index (GDVI) for dry land Characterization. Remote Sensing, 6: 1211-1233.

34. Xu, H., 2006. Modification of normalised difference water index (NDWI) to enhance open water features in remotely sensed imagery. In. J. Remote Sens., 7: 3025-3033.

35. Youssef, A.M., Pradhan, B., Sefry, S.A., 2015. Remote sensing-based studies coupled with field data reveal urgent solutions to avert the risk of flash floods in the Wadi Qus (east of Jeddah) Kingdom of Saudi Arabia. Nat. Hazards. 75: 1465-1488. 